\title{
REVITALIZATION OF BIOMASS FUEL BY IMPLEMENTING UB EARTHEN FURNACE TO SUPPORT THE SOCIETY'S SUSTAINABILITY OF ENERGY: A CASE STUDY IN THE SUBDISTRICT OF DAU, MALANG
}

\author{
Agus Suman \\ Faculty of Economics and Business, Brawijaya University \\ M. Nurhuda \\ Faculty of Mathematics and Natural Sciences, Brawijaya University
}

\begin{abstract}
The objectives of this study are to examine the likelihood of society in turning the use of the traditional and gas furnaces to the UB earthen furnace and to examine the potential reduction of the use of firewood and gas furnaces at Dau Subdistrict of Malang. Using descriptive analysis, this study found that the use of UB earthen furnace is able to reduce the use of firewood and gas furnace up to $50 \%$ and people's tendency in willing to turn both firewood and gas furnaces into the earthen furnace increases up to $60 \%$ dealing with its benefits and costs which have been observed by several main aspects (including economical, technical, environmental, social, and health aspects).
\end{abstract}

Keywords: Traditional furnace, gas furnace, firewood, and UB earthen furnace.

JEL Classifications: Q35, Q42

\section{INTRODUCTION}

Survey by Ministry of Energy and Mineral Resources in 2010 demonstrated that the composition of energy use in Indonesia is still dominated by fossil fuel (48.4\%), natural gas (28.6\%), coal (18.8\%), natural gas $(2.7 \%)$, hydro energy $(2.7 \%)$, and geothermal $(1.6 \%)$. The high use of fossil fuel energy also illustrates that people's dependence on fossil fuels remains high, contributing significantly to the people's daily life as well as triggering economic and social problems within the country. In the future, the dependence of national energy on the fossil fuel should be reduced due to the country's economic development sustainability.

We might predict that the assurance of energy availability in Indonesia become limited in the coming years. Until now, it is evident that Indonesia's oil reserve is only 
Revitalization of biomass fuel by implementing ub earthen furnace to support the society's sustainability of energy

about 3.7 billion barrels. Since 1987, there has also not been found a new giant oil field with a huge amount of oil reserve. Without any sufficient exploratian activities, therefore it is predicted that Indonesia will suffer from a serious energy crisis in the future.

Using firewood as the source of energy, particularly for people living in the rural areas, has proven to be dilemmatic, especially when it takes into account the environmental aspects as well as the health problems. The high need of fuel is the reason of people's for cutting trees in the forests which leads to deforestation. In practice, it is contraproductive with the government's program in preserving the enviroment. On the other hand, the high use firewoods in simple (traditional) furnace technology might result in excessive smoke which potentially causes respiratory problems including severe respiratory infection (ISPA).

As a result, it is vital to find solutions on this matter so that peple can keep using firewoods as the source of energy in a more efficient and environmentally friendly way. The alternative solution is by developing Biomass furnace which can produce a much better burning than the traditional one and save at least $50 \%$ of the need of fuel. It is an innovative solution that we have developed using clay called UB earthen furnace.

This study is aimed to examine the people's likelihood in using UB earthen furnace which is more economical and efficient compared to the use of traditional furnace or gas (LPG) stove, as well as to understand the effect of UB earthen furnace use on the reduction of firewood and LPG consumption before and after the usage.

This paper is started with an introduction, then, in the second part it is continued to discuss the research method. The third part discuss the result and discussion, while the last part concludes.

\section{RESEARCH METHOD}

This study was conducted at RT/RW: 01\&02/01 of Dau subdistrict, Malang District considering a significant proportion of population that use the firewood for cooking energy. Prior to this research, an introductory survey was held to determine the location and the correspondence with the local authority. 
The data used in this study include both primary and secondary data. The former was directly obtained through In-depth interview, Focus Group Disscusion (FGD), and questionnaire method to 100 respondents, i.e. the people who were using firewood and LPG for cooking energy. The data collection method was conducted by distributing questionnaires and data filling forms. As for the latter, the information was obtained from the governmental institutions and the BPS provincial and regional offices. Field survey was conducted from October 2012 to January 2013. The questionnaire is conducted necessarily to support intuitive assessment related to the determination of quality and the proportion required in the analysis method. There are two types of questionnaire which are distributed; they are the one distributed before the UB earten furnace is provided and the other, after they receive and use the UB earten furnace at least for 1 month.

\section{RESULT AND DISCUSSION}

\section{Characteristics of Respondents Before the Distribution of UB Earten Furnace}

Based on the survey conducted before the distribution of UB earthen furnace, it is found that all of the respondents (100\%) use traditional furnace and $98 \%$ of respondents also use gas (LPG) stove. Therefore, it can be clearly seen that most of the respondents depend on the use of firewood and LPG to fulfill their daily cooking needs.

The most common reason for people in using traditional furnace (87\%) is the fact that they believes traditional furnace can save their expense compared to buying oil gas and LPG. This condition is supported by the fact that the cost of getting a set of LPG stove (along with a $3 \mathrm{~kg}$ gas tube) is as much as Rp250,000,- and as much as Rp100,000,- for gas oil stove. Meanwhile, building a traditional furnace (using bricks cemented with sand) can be provided with only Rp. 50,000,- and last for 5-10 years.

The number of firewood use depends on the people's cooking needs. The majority of people need firewood to prepare ther daily meal and to heat water. Some people need 1 or 2 bundles of firewood per week which they can collect easily from around the house, backyard, or around rice field since the resources are still abundant. In contrast, to buy an 
Revitalization of biomass fuel by implementing ub earthen furnace to support the society's sustainability of energy

LPG, they need to spend much more money and sometimes LPG is difficult to get because of the distance from the city and the frequent delay of its distribution by the government.

Apart from the efficiency, the use of traditional furnace for daily cooking is considered more comfortable than using LPG stove. For special occasions, people also prefer this kind of furnace to cook because of the condition of traditional kitchen as well as more economical.

The major problem experienced by the respondents from the usage of traditional furnace is the large amount of smoke produced which is sometimes very disturbing. This condition is happened because the firewood used is not well dried so the fire frequently dies out during the cooking process. Besides the potential health problem, smoke can also influencing the global warming if the smoke produced from the traditional furnace is excessive. Furthermore, smoke can ruin the taste of the food processed due to that it can produces a burned aroma. Kitchen appliances can also turn black if they exposed to smoke everyday.

Regarding the reason for not using LPG, $61.9 \%$ or respondents state that there is a fear of explosion that might endanger their house and family. This apprehension is mainly caused by the lack of training and counseling to the society regarding the safe use of LPG. Those who have less knowledge prefer not to use LPG and believe that the traditional furnace is safer.

In terms of expense, $33.33 \%$ respondents mention that cooking with LPG is considered wasteful. Respondents usually need 2-3 of 3kg tubes of LPG per month for their daily needs, mainly for preparing meals for the family, with an estimated spending of Rp.25,000-Rp.50,000. Compared to those who can easily find firewoods, using LPG is undoubtedly believed to be less economical. The difficulty in obtaining LPG is another reason for people not to use it. The dearth of LPG frequently occurs due to the delay of supply to the area which results in the problem for people to use it continuously. 
Based on the data from survey before the distrubution of earten furnace, majority of respondents use traditional furnace for daily cooking. However, they actually realize that the traditional furnace has a lot of weaknesses; therefore, they hope that there is a furnace which is more economical, easier to use, smaller risk, more stable fire, and less polluting. Based on these considerations, the survey result demonstrates that the majority of people (94.23\%) inquires a cooking appliance/biomass furnace that is more flexible, smaller, and also easier to move.

\section{Characteristics of Respondents After the Distribution of UB Earthen Furnace: The Need of Firewood per Month}

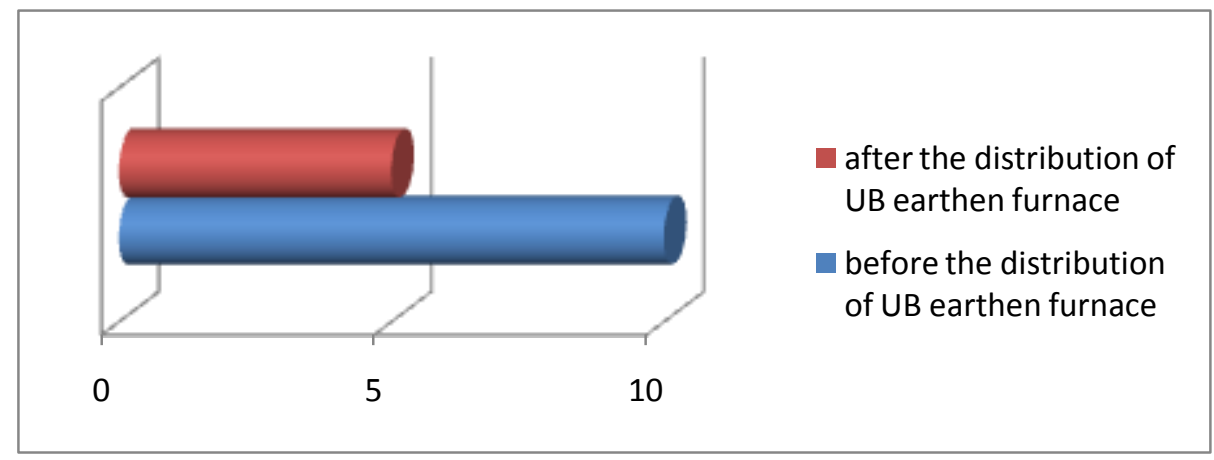

Figure1. The need of firewood per month Source: Field Data

Based on the result of 100 respondents, it is found that the need of firewood before the distribution of the UB furnace is 10 bundles per month, while after the distribution it is reduced to 5 bundles (50\% reduced). This is quite reasonable considering the size of UB earthen furnace's opening which is very small, thereby requiring small size of firewood which in turn can save the use of firewoods. Using the same assumption, if people continuously and consistently use UB earthen furnace, it might reduce the potential of firewood utilization in the area every year.

\section{The Need of 3 kg LPG per Month}


Revitalization of biomass fuel by implementing ub earthen furnace to support the society's sustainability of energy

In general, respondents rarely use LPG and only use it when there is a special need (not a daily usage). By looking at figure 2, the need of $3 \mathrm{~kg}$ LPG per month after the distribution of UB earthen furnace also decreased by a half (50\%). This is quite reasonable because UB earthen furnace provides more alternative of cooking utensil which in turn reduces the usage of $3 \mathrm{~kg} \mathrm{LPG}$ per month. Moreover, most of the respondents (90\%) feel that the price of LPG is expensive that it accentuates their economic burden.

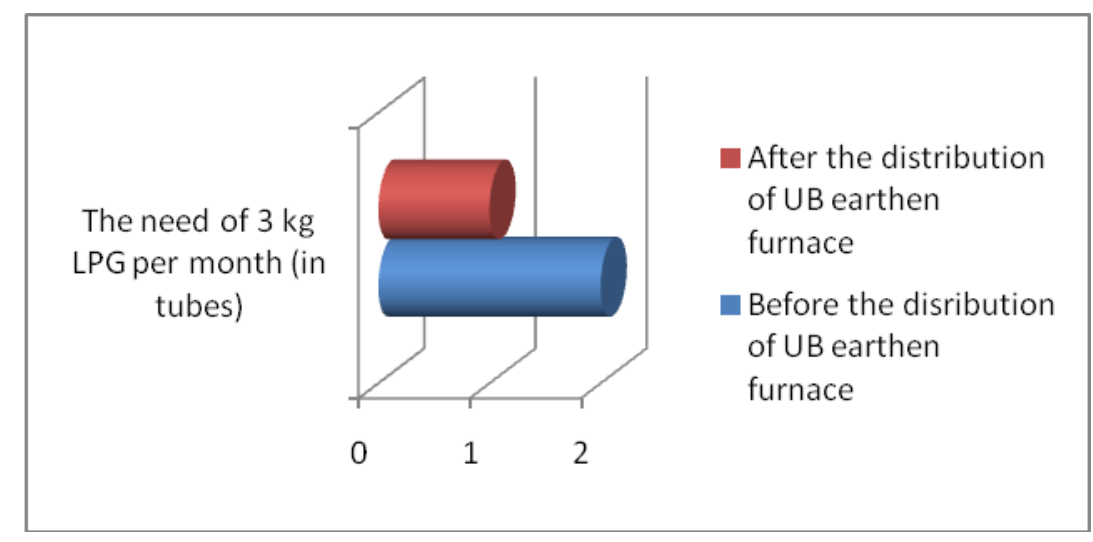

Figure 2. The need of $3 \mathrm{~kg}$ LPG per month

Source: field data

\section{The Efficiency of Firewood using UB Earthen Furnace Compared to Traditional Furnace}

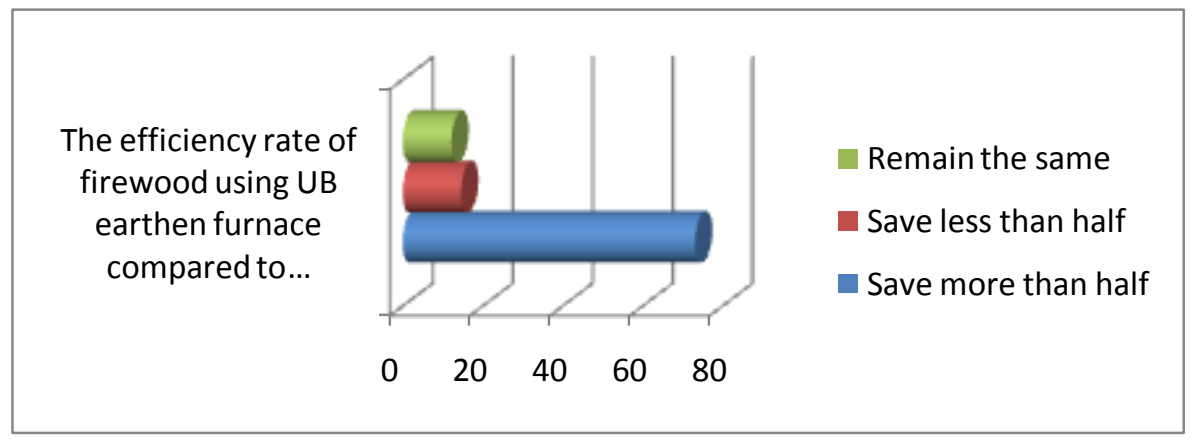

Figure 3. The efficiency rate of firewood using UB earthen furnace compared to traditional furnace

Source: Field Data 
Based on figure 3, it can be seen that $73.17 \%$ respondents believe that the efficiency rate of firewood can save the use of firewood by more than half and $14.63 \%$ of respondents believe that it can save less than a half, whereas only $12,2 \%$ of respondents who mention that there is no difference in terms of efficiency. These respondent's perceptions are quite logical since the fact shows that the use of firewood by the society keeps decreasing day by day due to the use of UB earthen furnace which does not require a huge amount of firewood.

\section{The Decreasing Use of LPG stove after Using UB Earthen Furnace}

One of the main purposes of earthen furnace is reducing the need and the use of LPG which is more expensive and has a potential to cause accidents. From all of the respondents, 69.04\% said that they use LPG stove less after the distribution of UB earthen furnace and $11.90 \%$ respondents even do not use it anymore. Meanwhile, the rest $119.06 \%$ respondents) are still using LPG stove without any changes.

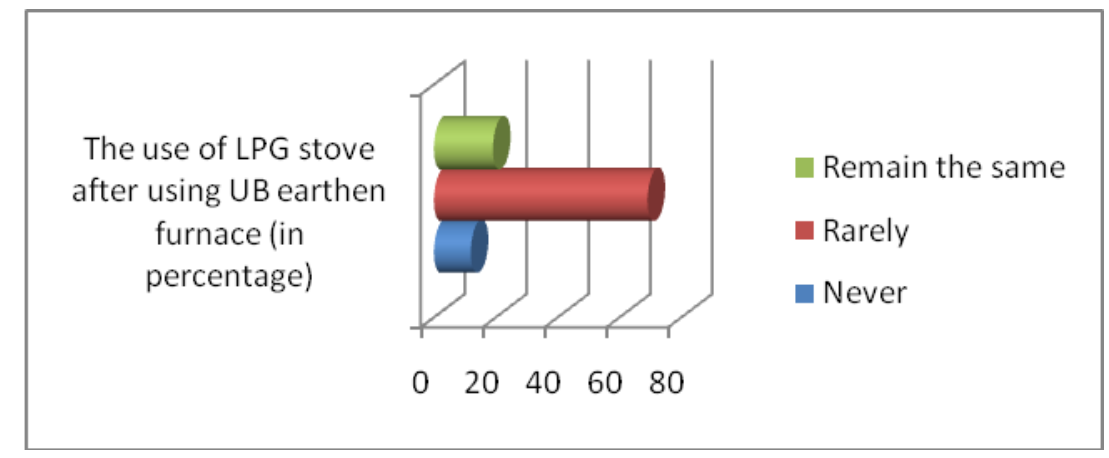

Figure 4. The use of LPG Stove after using UB earthen furnace Source: Field Data

\section{The Cooking Speed by Using UB Earthen Furnace Compared to Traditional Furnace}

Apart from the economic aspects, UB earthen furnace also has its benefit in terms of its quality, i.e. it cooks faster than the traditional furnace. From all of the respondents, $41 \%$ said that it is faster to cook using UB earthen furnace than the traditional one while $36 \%$ of respondents feel that it is relatively slower. In addition, the remaining 23\% respondents 
Revitalization of biomass fuel by implementing ub earthen furnace to support the society's sustainability of energy

feels there is no different in cooking speed between earthen furnace and traditional furnace (equally fast).

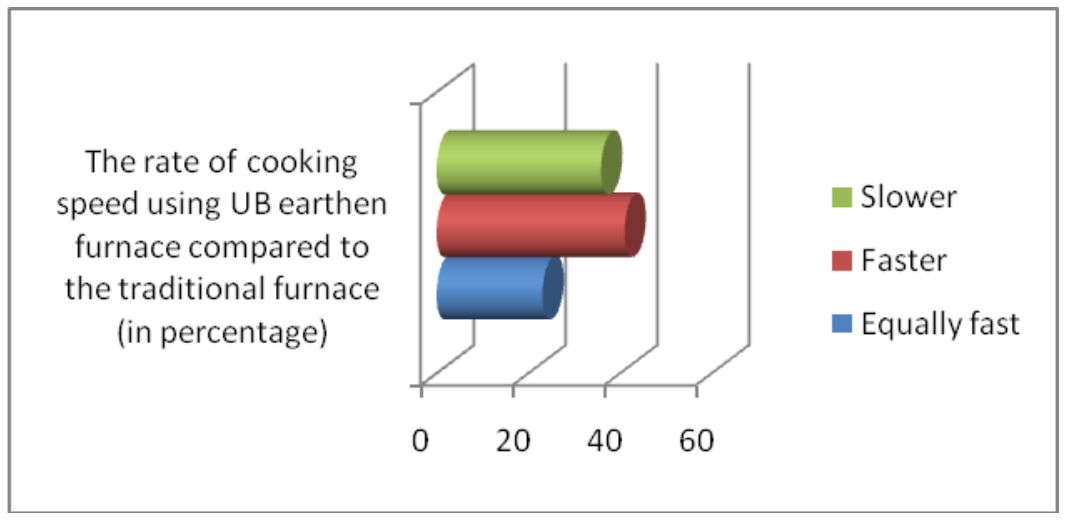

Figure 5.The cooking speed using UB earthen furnace compared to traditional furnace Source: Field Data

\section{The Suitability of UB Earthen Furnace with the Household Cooking Need}

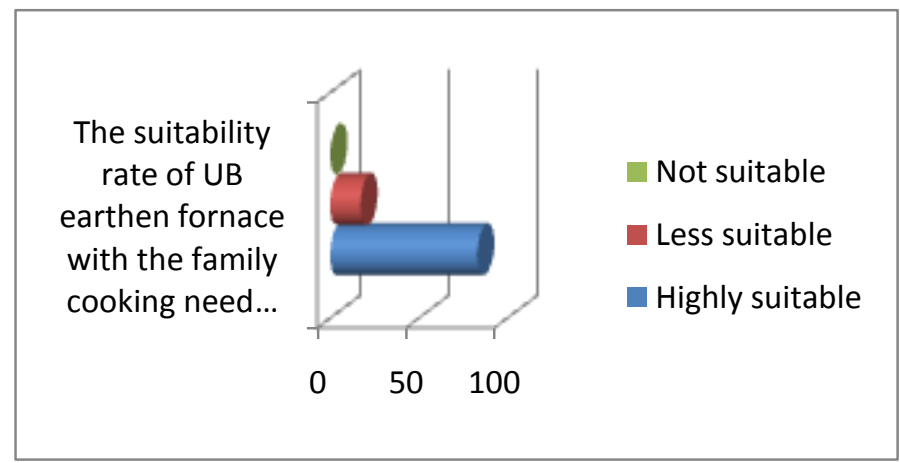

Figure 6. The suitability rate of UB Earthen Furnace with the family cooking need Source: Field Data 
The Decreasing Use of Firewood and LPG after the Implementation of UB Earthen Furnace

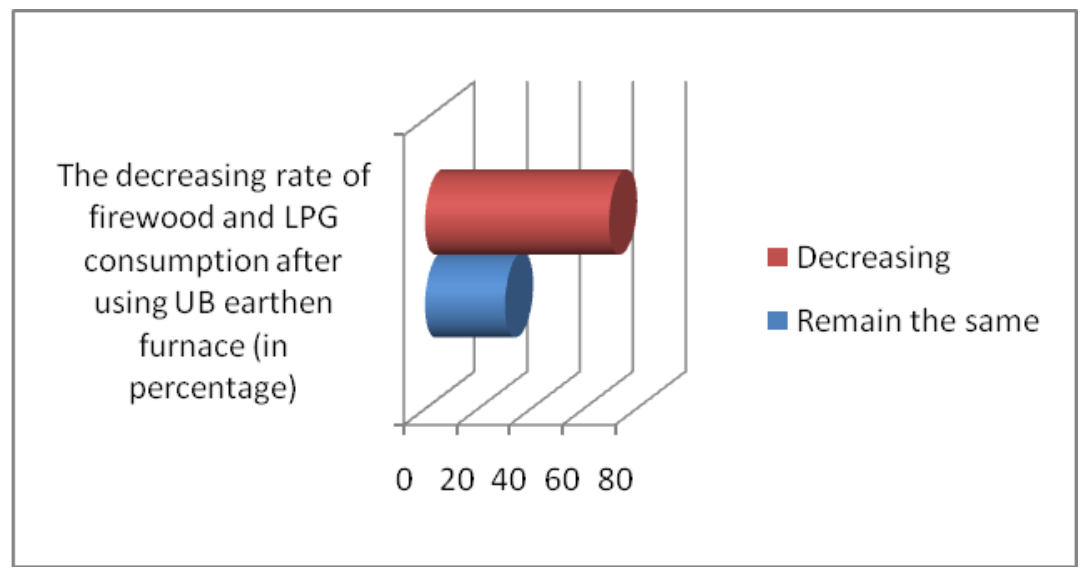

Figure7. The decreasing rate of firewood and LPG use after the implementation of UB earthen furnace

Source: Field Data

Next, we try to analyze the consumption of firewood and LPG after the development of UB earthen furnace. Based on the survey, 70\% respondents feel that UB earthen furnace can definitely reduce the use of firewood and LPG, while the remaining $30 \%$ believe that there is no difference in the consumption of firewood and LPG (remain the same). The higher proportion of respondents believing that UB earthen furnace can reduce the LPG and firewood usages is not surprising due to the fact that the earthen furnace is more efficient, economical, and hygienic (concerning the aspect of economy, social, environment, and health).

People's tendency to turn from traditional furnace to UB earthen furnace 
Revitalization of biomass fuel by implementing ub earthen furnace to support the society's sustainability of energy

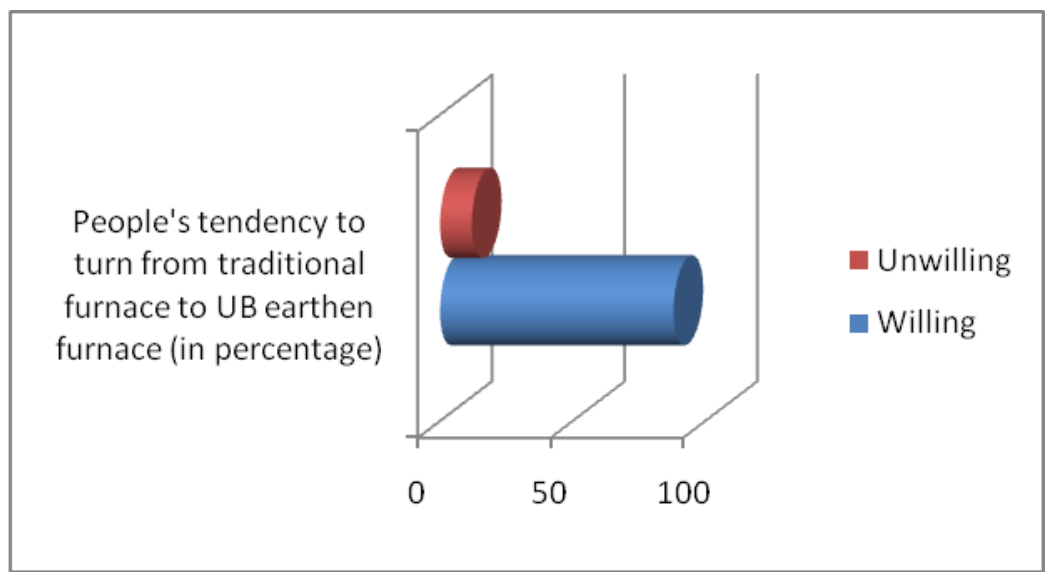

Figure 8. People's tendency to turn from traditional furnace to UB earthen furnace Source: Field Data

Moreover, from the respondents, it is found that $88 \%$ of them are willing to move from the traditional furnace to UB earthen furnace, whereas $12 \%$ of respondents are unwilling. Those of the former opinion believe that UB earthen furnace is faster, more efficient, more economical, more flexible, and has many advantages compared to the traditional furnace. Meanwhile, those who are against the UB earthen furnace argue that the traditional furnace is more convenient particularly for a big cooking.

\section{People's Tendency to Move from LPG to UB Earthen Furnace}

From the respondents, it is also acknowledged that $96 \%$ of respondents are willing to move from LPG stove to UB earthen furnace while the rest (4\%) refuse to change. Most respondents are commonly willing to turn from LPG stove due to its high cost, when it is seen from such aspects including economy, environment, and risk compared to UB earthen furnace. Moreover, the price of LPG fuel might increase anytime since there is a possibility that its subsidy will be removed by the government, putting much burden economically for those who live particularly in rural areas. 


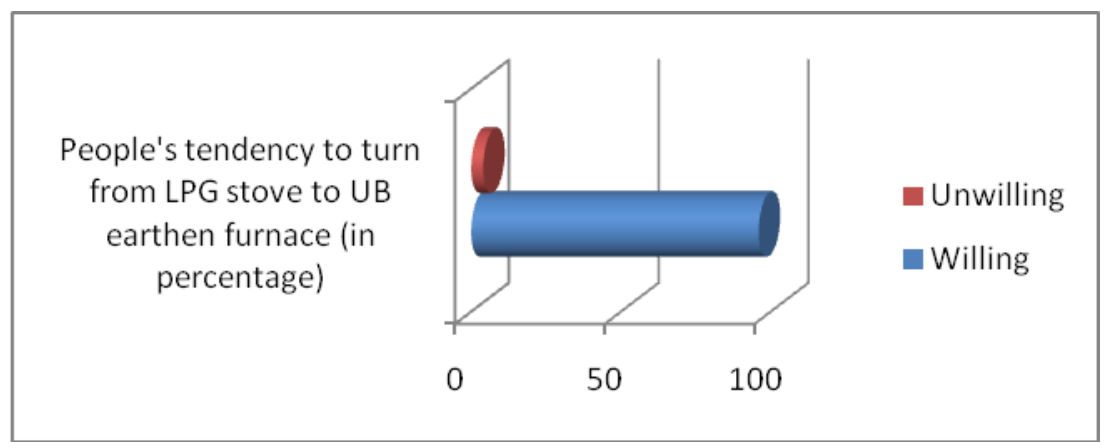

Figure 9. People's tendency to turn from LPG to UB earthen furnace Source: Field Data

From the quantity aspect, the UB earthen furnace can cook faster compared to the traditional furnace, because its quick flame results in an intense burning power making the food is quickly prepared. This is supported by the statement of $41 \%$ respondents who claim that cooking by UB earthen furnace is faster compared to the traditional furnace. Similarly, the frequency of inserting firewoods decreases so the people do not have to wait for a long time in front of the furnace only to insert the woods which means that they can make use of the time to do other more productive and useful activities.

\section{CONCLUSIONS}

The use of UB earthen furnace can reduce the consumption of firewood and $3 \mathrm{~kg}$ LPG fuels up of $40 \%-50 \%$, which makes it preferable by the majority of respondents. Besides more efficient and economical, the UB earthen furnace also offers such benefits as faster food processing and more environmentally friendly quality than the traditional furnace and LPG stove. Apart from its weaknesses, UB earthen furnace provides an alternative cooking appliance in the future to create energy sustainability of the people with the basis of biomass fuel. In practice, the use of UB earthen furnace needs to studied further by adding the research period, the number of users, and the number of respondents to obtain the more relevant, accurate, and reliable findings with good quality and high reliability. 
Revitalization of biomass fuel by implementing ub earthen furnace to support the society's sustainability of energy

\section{REFERENCES}

Badan Pusat Statistik Propinsi Jatim. (2011). Propinsi Jatim Dalam Angka

Bowe, S. (2001). Forestry Facts. Dept. Of Forest Ecology and Management, Univ. Of Wisconsin. Website: http://forest.wisc.edu/extension. Accexxed on August 1, 2012.

Budimanta, A. (2015). Memberlanjutkan Pembangunan di Perkotaan melalui Pembangunan Berkelanjutan dalam Bunga Rampai Pembangunan Kota Indonesia dalam Abad 21.

Djajadiningrat, T. (2005), Suistanable Future: Menggagas Warisan Peradaban bagi Anak Cucu, Seputar Pemikiran Surna.

Badan Pusat Statistik Kabupaten Malang. (2010). Kabupaten Malang Dalam Angka 2010.

Mathews, E. (2009). Undying Flame: The Continuing Demand for Wood as Fuel. World resource Institute. Accessed fom: http//earthtrends.wri.org/text/energyresources/feature-3.html on August 3, 2012.

Nurhuda, M "Tungku Biomass Dengan Pemasukan Bahan Bakar Dari Samping Dan Pembakaran Secara Turbulen", Patent listed by Dirjen HaKI, No. P00201200468

Moleong, L. J. (2007). Metodologi Penelitian Kualitatif. Revised Edition. Cetakan keduapuluh empat. Remaja Rosdakarya, Bandung.

_ BP Statistical Review of World Energy June 2010, [online], (http:// www.bp.com/statisticalreview, accessed on June 12, 2012.

, Harga BBM Dalam Negeri, [online], (http://www.esdm.go.id/ publikasi/hargaenergi/harga-bbm-dalam-negeri.html, accessed on June 4, 2012.

Indonesia Energy Statistic, [online], (http://www.esdm.go.id/publikasi/ indonesiaenergy-statistics-leaflet.html, accessed on June 4, 2012.

— Abdullah, Gamil. 2011. Berakhirnya Era Harga Minyak Rendah. [pdf], (http://www.migas-indonesia.net, accessed on June 9, 2012.

Partowidagdo, W. (2010)_. Ketahanan Energi Nasional. [pdf], (http://www.migasindonesia.net, diakses accessed on June 9, 2012. 
Ringkasan Eksekutif Indonesia Energy Outlook 2009. The Ministry of Energy and Mineral Resources.Jakarta:2009

World Bank. (1998)."The Initiative on Defining, monitoring and Measuring Social Capital: Text of Proposal Approved for Funding".Social Capital Initiative Working Paper No. 2.The World Bank, Social Development Family, Environmentally and Socially Sustainable DevelopmentNetwork. Accessed from http://www1.worldbank.org/prem/poverty/ scapital/wkrppr/sciwp2.pdf. on May 9, 2005

http://en.wikipedia.org/wiki/Rocket stoveDefinition of a Rocket stove

http://www.bioenergylists.org/stovesdoc/Still/Rocket\%20Stove/Principles.html Larry Winiarski's Rocket Stove Principles (Dean Still)

http://www.bioenergylists.org/stovesdoc/Design/Design.html Biomass Cookstove Design and Testing

http://www.ehow.com/how 2265305 build-winiarski-rocket stove.html\#ixzz1H5MC0jJa How to Build a Winiarski Rocket Stove 